\title{
Árangur kransæðahjáveituaðgerða hjá sjúklingum fimmtíu ára og yngri
}

Linda Ó. Árnadóttir ${ }^{1}$ læknanemi, Tómas A. Axelsson ${ }^{1}$ læknanemi, Daði Helgason ${ }^{1}$ læknanemi, Hera Jóhannesdóttir ${ }^{1}$ læknanemi, Jónas A. Aðalsteinsson ${ }^{1}$ læknanemi, Arnar Geirsson² læknir, Axel F. Sigurðsson³ læknir, Tómas Guðbjartsson ${ }^{1,2}$ læknir,

\section{ÁGRIP}

Inngangur: Meðalaldur peirra sem gangast undir kransæðahjáveituaðgerð er nálægt sjötugu. Tilgangur rannsóknarinnar var að kanna árangur kransæðahjáveituaðgerða hjá yngri sjúklingum ( $\leq 50$ ára), meðal annars snemmkomna fylgikvilla, dánartíoni innan 30 daga og langtímalifun.

Efniviður og aðferðir: Afturskyggn rannsókn á 1626 sjúklingum sem gengust undir kransæðahjáveituaðgerð á Landspítala 2001-2012. Bornir voru saman 100 sjúklingar 50 ára og yngri og 1526 sjúklinga yfir fimmtugu. Niðurstöður: Hlutfall karla og áhættupættir kransæðasjúkdóms voru sambærilegar í báđum hópum, einnig útbreiðsla kransæðasjúkdóms og hlutfall sjúklinga með vinstri höfuðstofnsprengsli. Útstreymisbrot vinstri slegils yngri sjúklinga fyrir aðgerð var marktækt lægra en peirra eldri (52\% á móti $55 \%, p=0,004)$, fleiri peirra höfðu nýlegt hjartadrep fyrir aðgerð (41\% á móti $27 \%, p=0,003)$ og aðgerð var oftar gerð með flýtingu (58\% á móti $45 \%, p=0,016)$. Tíoni minniháttar fylgikvilla var lægri hjá yngri sjúklingum (30\% á móti $50 \%, p<0,001)$, sérstaklega nýtilkomið gáttatif (14\% á móti 35\%, $p<0,001$ ), en blæðing í brjóstholskera á fyrsta sólarhring eftir aðgerð var einnig minni (853 ml á móti $999 \mathrm{ml}, \mathrm{p}=0,015)$ og peir fengu færri einingar af rauðkornapykkni (1,3 á móti 2,8 ein, $p<0,001)$. Hins vegar reyndist ekki marktækur munur á alvarlegum fylgikvillum (6\% á móti $11 \%, p=0,13$ ) eđa dánartíoni innan 30 daga ( $1 \%$ á móti $3 \%, p=0,5)$. Legutími yngri sjúklinga var rúmlega tveimur dögum styttri að meðaltali en peirra eldri $(p<0,001)$. Sjúkdómasértæk lifun var sambærileg fyrir báđa aldurshópana en pó sást tilhneiging í átt að betri lifun fyrir yngri sjúklinga (99\% á móti 95\% fimm ára lifun, $p=0,07$ ).

Ályktun: Minniháttar fylgikvillar eru sjaldgæfari hjá yngri sjúklingum en peim eldri, legutími peirra er styttri og blóðgjafir fátíðari. Einnig virðast veikindi peirra bera bráđar að. Sjúkdómasértæk lifun yngri sjúklinga virðist ívið betri en eldri sjúklinga.
Fyrirspurnir: Tómas Guðbjartsson tomasgud@landspitali.is

Greinin barst 3. desember 2013 sampykkt til birtingar 29. september 2014. gefin upp.
Inngangur

Kransæðahjáveituaðgerð er langalgengasta opna hjartaaðgerðin á Vesturlöndum og er oftast beitt við útbreiddum kransæðasjúkdómi og/eða prengslum í höfuðstofni vinstri brjóstholsslagæðar. ${ }^{1-3}$ Áhætta á kransæðasjúkdómi eykst með aldri en flestir sjúklingar sem gangast undir hjáveituaðgerð eru komnir fast að sjötugu og gera má ráð fyrir að yfir 97\% peirra lifi aðgerðina. ${ }^{4-6}$ Áhættupættir kransæðasjúkdóms hjá yngri sjúklingum eru ekki eins vel rannsakaðir og hjá peim eldri. Pó hafa reykingar og sykursýki, sérstaklega hjá konum, tengsl við snemmkominn kransæðasjúkdóm.,8 Einnig virðast karlar fá kransæðasjúkdóm fyrr, sérstaklega peir sem eru í ofpyngd. ${ }^{79}$ Fjölskyldusaga er einnig mikilvægur áhættupáttur en rannsóknir benda til að erfðapættir geti leikið stórt hlutverk í próun snemmkomins kransæðasjúkdóms. ${ }^{10}$

Hér á landi hefur árangur kransæðahjáveituaðgerða verið töluvert rannsakaður, meðal annars hjá eldri sjúklingum og peim sem pjást af offitu. ${ }^{6,11,12}$ Hins vegar er lítið vitað um árangur hjá yngri sjúklingum, en í erlendum rannsóknum eru peir um 5-7\% peirra sem gangast undir hjáveituaðgerð..$^{33,14}$

Tilgangur pessarar rannsóknar var pví að kanna árangur kransæðahjáveituaðgerða hjá sjúklingum 50 ára og yngri og bera saman við eldri sjúklinga. Sérstaklega var litið á snemmkomna fylgikvilla og dánartíðni innan 30 daga en einnig langtímalifun eftir aðgerð.

\section{Efniviður og aðferðir}

Rannsóknin var afturskyggn og tók til allra peirra 1626 sjúklinga sem gengust undir sína fyrstu kransæðahjáveituaðgerð á Landspítala á tímabilinu 1. janúar 2001 til 31. desember 2012. Endurhjáveituaðgerðum var sleppt og aðgerðum par sem önnur hjartaaðgerð var gerð samtímis kransæðahjáveitu, eins og hjartalokuskipti eða hjartalokuviðgerð.

Leitað var að sjúklingum í tveimur aðskildum skrám og með pví reynt að tryggja að allir sjúklingar væru teknir með í rannsóknina. Annars vegar var leitað í sjúklingabókhaldi Landspítala eftir aðgerðarnúmerum fyrir kransæðahjáveituaðgerðir (FNSA00, FNSC10, FNSC20 og FNSC30) og aðgerðir par sem notuð var hjarta- og lungnavél (FZSA00 og FZSA10). Hins vegar var stuðst við skrá sem haldin er á hjarta- og lungnaskurðdeild Landspítala og nær til allra opinna hjartaaðgerða, en frá 2010 hefur pessi skráning verið rafræn.

Klínískar upplýsingar fengust úr sjúkraskrám, аðgerðarlýsingum og svæfingarskýrslum, meðal annars um ýmsa áhættupætti kransæðasjúkdóms, aðgerðina sjálfa og fylgikvilla eftir aðgerð. Skráð var kyn og aldur við aðgerð en einnig reiknaður líkamspyngdarstuðull $\left(\mathrm{kg} / \mathrm{m}^{2}\right)$ út frá upplýsingum um hæð og pyngd. Einkenni sjúklinga voru stiguð eftir kvörðum CCS (Canadian Cardiovascular Society) og NYHA (New York Heart Association). Einnig var fyrri hjartasaga skráð, til dæmis saga um nýlegt og eldra hjartadrep, kransæðavíkkun og 
Tafla I. Áhættupættir fyrir kransæðasjúkdómi i yngri og eldri hópi. Gefinn er upp fjöldi (\%), nema meðaltal \pm staðalfrávik (bil) fyrir líkamspyngdarstuðul.

\begin{tabular}{|c|c|c|c|}
\hline Áhættupáttur & Yngri $\leq 50$ ára & Eldri >50 ára & p-gildi \\
\hline Reykingasaga & $68(69)$ & $1077(72)$ & 0,74 \\
\hline Blóðfituröskun & $62(63)$ & $855(58)$ & 0,32 \\
\hline Háprýstingur & $57(57$ & $981(64)$ & 0,17 \\
\hline Sykursýki & $20(20)$ & 241 (16) & 0,34 \\
\hline $\begin{array}{l}\text { Líkamspyngdarstuðull, } \\
\qquad \mathrm{kg} / \mathrm{m}^{2} \text { (bil) }\end{array}$ & $\begin{array}{l}29,1 \pm 4,8 \\
(21,2-46,3)\end{array}$ & $\begin{array}{l}28,1 \pm 4,4 \\
(17-63,9)\end{array}$ & 0,06 \\
\hline
\end{tabular}

hjartsláttaróreglu. Einnig voru skráð hjartalyf sem sjúklingarnir tóku fyrir aðgerðina. Farið var yfir niðurstöður kransæðapræðingar úr præðingalýsingum fyrir aðgerð og metið hvort um priggja æða kransæðasjúkdóm og/eða vinstri höfuðstofnsprengsli væri að ræða. Að auki var farið yfir ómskoðunarsvör og útstreymisbrot vinstri slegils skráð í prósentum, auk hlutfalls sjúklinga sem höfðu útstreymisbrot undir 30\%. Staðlað EuroSCORE var reiknað fyrir alla sjúklinga fyrir aðgerð en pað er alpjóðlega viðurkennt áhættulíkan til að meta áhættu við hjartaskurðaðgerðir. ${ }^{15}$

Litið var til pess hvort aðgerðin var framkvæmd með aðstoð hjarta- og lungnavélar eða á sláandi hjarta. Aðgerðartími (skin to skin), tími á hjarta- og lungnavél og tangartími (cross clamp time) var skráður í mínútum. Athugaður var fjöldi fjærtenginga á kransæðar (distal anastomosis) ásamt pví hvaða græðlingar voru notaðir við hjáveituna, bláæða- eða slagæðagræðlingar. Aðgerðir voru flokkaðar eftir pví hvort um var að ræða val-, flýti- eða bráðaаðgerð. Bráðaaðgerð var skilgreind sem aðgerð gerð innan sólarhrings frá komu sjúklings á sjúkrahús, flýtiaðgerð ef aðgerð var gerð á sjúklingi sem var inniliggjandi á sjúkrahúsi en valaðgerð ef sjúklingur var innkallaður af biðlista. Legutími á gjörgæslu og legudeild hjartaskurðlækninga var skráður í dögum. Blæðing í brjóstholskera fyrsta sólarhringinn var skráð í ml og fjöldi eininga rauðkornapykknis sem sjúklingum voru gefnar í eða eftir aðgerð var einnig skráður.

Fylgikvillar voru flokkaðir í alvarlega og minniháttar og var að hluta til stuðst við skilmerki Society of Thoracic Surgeons (STS). ${ }^{16}$ Fylgikvillar sem greindust á fyrstu 30 dögum eftir aðgerð voru skilgreindir sem snemmkomnir. Alvarlegir fylgikvillar voru hjartadrep í eða eftir aðgerð, heilablóðfall, djúp sýking (sýking í bringubeini eða miðmæti) bráður nýrnaskaði í RIFLE-flokki F og E, og fjöllíffærabilun. Minniháttar fylgikvillar voru nýtilkomið gáttatif, grunnar skurðsárasýkingar á bringu eða fæti, lungnabólga, pvagfærasýkingar, aftöppun fleiðruvökva og vægur nýrnaskaði (RIFLE-flokkar R og I). Hjartadrep í eða eftir aðgerð var skilgreint sem nýtilkomnar ST-hækkanir eða vinstra greinrof á hjartalínuriti ásamt hækkun á hjartaensíminu CKMB yfir $70 \mathrm{ng} / \mathrm{ml}$, en pá voru ekki teknir með sjúklingar sem höfðu hækkun á CKMB vegna hjartadreps fyrir aðgerð. Sérstaklega var athugað hvort sjúklingur purfti að fara í víkkun á kransæðum eða endurhjáveituaðgerð innan 30 daga vegna endurprengsla. Loks var dánartíðni innan 30 daga frá aðgerð (operative mortality) skráð.

Heildarlifun og sjúkdómasértæk lifun var reiknuð með aðferð Kaplan-Meier og samanburður á lifun yngri og eldri hóps metinn með log-rank prófi. Við útreikninga á sjúkdómasértækri lifun voru einungis taldir með sjúklingar sem létust af völdum hjarta- og æðasjúkdóma. Útreikningar á lifun miðuðust við 1. maí 2013 en upplýsingar um dánarorsakir fengust úr dánarmeinaskrá Emb- ættis landlæknis. Áhættulíkan Cox var notað til pess að kanna fylgni breyta við langtímalifun.

Gögn voru skráð í forritið Microsoft Office Excel og lýsandi tölfræði unnin í pví en tölfræðipróf voru gerð í forritinu Rstudio-útgáfu 0.97.318. Marktækni miðaðist við p-gildi $<0,05$.

Áður en rannsóknin hófst fengust öll tilskilin leyfi frá vísindasiðanefnd, Persónuvernd og framkvæmdastjóra lækninga á Landspítala.

\section{Niðurstöður}

Af 1626 sjúklingum voru 100 (6\%) 50 ára og yngri og hélst petta hlutfall stöðugt á premur fjögurra ára tímabilum frá 2001 til 2012 ( $p>0,1)$. Í yngri hópnum var meðalaldur $46 \pm 3,6$ ár (bil: $32-50$ ) en $67 \pm 8,0$ ár í peim eldri (bil: 51-88). Í sömu hópum var hlutfall karla svipað, eða $87 \%$ og $82 \%(p=0,24)$.

Áhættupættir kransæðasjúkdóms, eins og saga um reykingar, háprýsting, blóðfituröskun og sykursýki, voru sambærilegir milli hópa (tafla I). Tilhneiging til hærri líkamspyngdarstuðuls sást í hópi yngri sjúklinga, eða $29 \mathrm{~kg} / \mathrm{m}^{2}$ borið saman við $28,1 \mathrm{~kg} / \mathrm{m}^{2}$ hjá eldri sjúklingum $(\mathrm{p}=0,06)$.

Einkenni voru svipuð í hópunum, bæði samkvæmt CCS- og NYHA-kvarða. Algengust var hjartaöng (64\% á móti 60\%, p=0,5), næstflestir höfðu hjartaöng ásamt mæði (32\% á móti 36\%, p=0,52) og $4 \%$ í báðum hópum kvörtuðu um mæði án brjóstverkja. Hlutfall sjúklinga með hvikula hjartaöng var einnig sambærilegt milli hópa (59\% á móti 51\%, p=0,16). Tveir sjúklingar í yngri hópi (2\%) og 18 í peim eldri (0,1\%) greindust fyrir tilviljun (oftast við eftirlit) og höfðu engin einkenni frá hjarta $(\mathrm{p}=0,35)$.

Hlutfall sjúklinga með priggja æða kransæðasjúkdóm (79\% á móti 83\%, p=0,43) og marktæk prengsli í vinstri höfuðstofni $(36 \%$ á móti $43 \%$, $\mathrm{p}=0,22)$ var sambærilegt milli yngri og eldri sjúklinga. Sama átti við um fyrri sögu um hjartasjúkdóma, par með talið eldra hjartadrep (30\% á móti 25\%, p=0,34), fyrri kransæðavíkkun ( $20 \%$ á móti $21 \%, p=1)$, hjartabilun ( $8 \%$ á móti $10 \%, p=0,73$ ) og hjartsláttaróreglu (7\% á móti 10\%, p=0,48). Fleiri yngri sjúklingar höfðu hins vegar sögu um nýlegt hjartadrep, eða 41 sjúklingur (41\%) borið saman við 408 (27\%) í peim eldri ( $\mathrm{p}=0,003)$.

Yngri sjúklingar höfðu marktækt lægra útstreymisbrot vinstri slegils (meðaltal 52\% $\pm 11,4$, bil: $15-70$ ) miðað við eldri hópinn (55\% $\pm 9,8$, bil: $10-80)(\mathrm{p}=0,004)$. Hlutfall yngri sjúklinga með útstreymisbrot undir $30 \%$ var $5 \%$ en $2 \%$ í eldri hópi $(p=0,03)$.

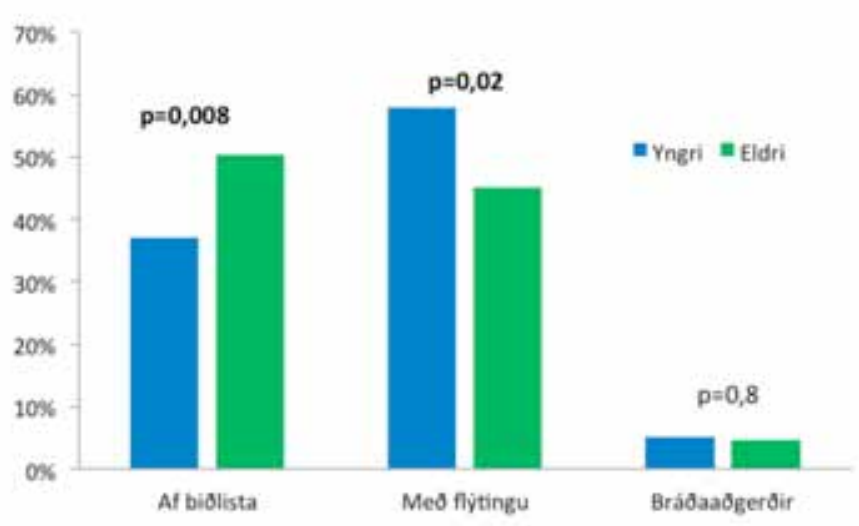

Mynd 1. Hlutfall sjúklinga í yngri og eldri hópi sem gengust undir valaðgerð, aðgerð með flýtingu eða bráðaaðgerð. 
Tafla II. Aðgerðartengdir pættir í yngri og eldri hópi. Gefinn er upp fjöldi (\%) eða meðaltal \pm staðalfrávik (bil).

\begin{tabular}{lccc}
\hline & Yngri $\leq 50$ & Eldri $>50$ & p-gildi \\
\hline Aðgerð á sláandi hjarta - OPCAB & $28(28)$ & $343(22)$ & 0,32 \\
\hline Aðgerðartími, mínútur (bil) & $\begin{array}{c}208 \pm 47 \\
(125-350)\end{array}$ & $\begin{array}{c}213 \pm 57 \\
(85-630)\end{array}$ & 0,4 \\
\hline Fjöldi fjærtenginga (bil) & $3,4 \pm 1(1-5)$ & $3,4 \pm 0,8(1-6)$ & 0,44 \\
\hline $\begin{array}{l}\text { Vinstri brjóstholsslagæð notuð } \\
\text { - LIMA }\end{array}$ & $93(93)$ & $1437(94)$ & 0,26 \\
\hline
\end{tabular}

Á mynd 1 sést hversu fljótt sjúklingarnir voru teknir til aðgerðar. Yngri sjúklingar voru oftar teknir í aðgerð með flýtingu (58\% á móti $45 \%$, $\mathrm{p}=0,016)$ en hlutfall bráðaaðgerða var svipað í báðum hópum, eða í kringum 5\% (p=0,8).

Hlutfall aðgerða sem gerðar voru á sláandi hjarta var svipað í báðum hópum, eða $28 \%$ í yngri hópi og $22 \%$ í peim eldri ( $\mathrm{p}=0,31$ ). Aðgerðartími, tími á hjarta- og lungnavél og tangartími var einnig svipaður í báðum hópunum. Fjöldi fjærtenginga á kransæðar var sambærilegur, sem og notkun LIMA-slagæðagræðlings (tafla II).

Blæðing í vinstri brjóstholsslagæð fyrstu 24 klst. eftir aðgerð var minni hjá yngri hópnum og munaði $146 \mathrm{ml}$ á hópunum (853 á

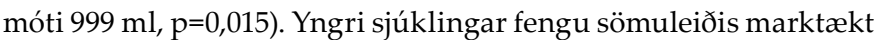
færri einingar af rauðkornapykkni í og eftir aðgerð og munaði 1,5 einingu í allri legunni (1,3 á móti 2,8 einingum, $p<0,001)$.

Tíðni allra minniháttar fylgikvilla samanlagt var marktækt lægri hjá yngri hópnum en par greindist um priðjungur sjúklinganna með einhvern minniháttar fylgikvilla eftir aðgerð borið saman við helming eldri sjúklinga (tafla III). Par munaði mestu um nýtilkomið gáttatif en pað var algengasti fylgikvillinn í báðum hópum og greindist hjá $14 \%$ yngri sjúklinga og 35\% peirra eldri $(\mathrm{p}<0,001)$.

Heildartíðni alvarlegra fylgikvilla var sambærileg í báðum hópum en 6 sjúklingar (6\%) í yngri hópnum greindust með alvarlegan fylgikvilla borið saman við 170 (11\%) í eldri hópnum ( $\mathrm{p}=0,13)$. Ekki sást heldur marktækur munur á tíðni einstakra alvarlegra fylgikvilla (tafla IV) ef frá er skilinn bráður nýrnaskaði (RIFLEflokkar F og E) en enginn greindist í yngri hópnum en 13 (0,8\%) í peim eldri $(\mathrm{p}<0,001)$.

Ekki var marktækur munur á dánarhlutfalli innan 30 daga milli hópa ( $\mathrm{p}=0,51)$. Í yngri hópnum lést einn sjúklingur innan 30 daga eftir aðgerðina (1\%) en sá sjúklingur lést 6 dögum eftir aðgerð vegna hjartabilunar og hjartsláttaróreglu. Í eldri hópnum

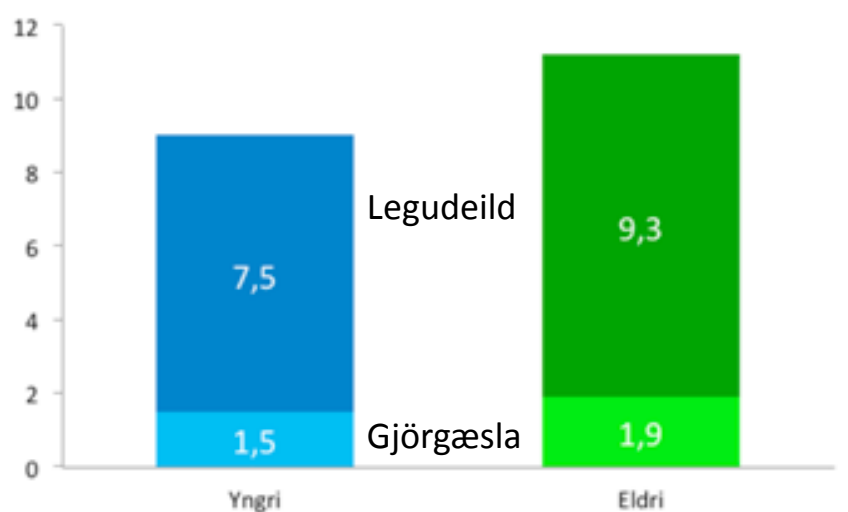

Mynd 2. Legutími yngri og eldri sjúklinga á gjörgæslu og á legudeild (dekkri litur) í dögum.
Tafla III. Minniháttar snemmkomnir fylgikvillar í yngri og eldri hópi eftir aðgerð. Fjöldi (\%).

\begin{tabular}{lccc}
\hline Fylgikvillar & Yngri $\leq 50$ ára & Eldri >50 ára & p-gildi \\
\hline Allir minniháttar fylgikvillar & $30(30)$ & $763(50)$ & $<0,001$ \\
\hline Gáttatif & $14(14)$ & $536(35)$ & $<0,001$ \\
\hline Aftöppun fleiðruvökva & $7(7)$ & $180(12)$ & 0,19 \\
\hline $\begin{array}{l}\text { Grunn skurðsýking í } \\
\text { bringubeinsskurði eða á fæti }\end{array}$ & $7(7)$ & $151(10)$ & 0,48 \\
\hline Pvagfærasýking & $0(0)$ & $55(4)$ & 0,04 \\
\hline Lungnabólga & $7(7)$ & $99(6)$ & 0,83 \\
\hline Bráður nýrnaskaði (RIFLE-flokkur R)* & $9(9)$ & $145(11)$ & 1 \\
\hline Bráður nýrnaskaði (RIFLE-flokkur l) & $1(1)$ & $41(3)$ & 0,51 \\
\hline
\end{tabular}

*Kreatíníngildi vantaði fyrir tvo sjúklinga í yngri hópi og 23 í peim eldri.

Tafla IV. Alvarlegir snemmkomnir fylgikvillar í yngri og eldri hópi eftir aðgerð. Fjöldi (\%).

\begin{tabular}{lccc}
\hline Fylgikvillar & Yngri $\leq 50$ ára & Eldri $>50$ ára & p-gildi \\
\hline Allir alvarlegir fylgikvillar & $6(6)$ & $170(11)$ & 0,13 \\
\hline Hjartadrep & $3(3)$ & $73(5)$ & 0,62 \\
\hline Bringubeinslos & $1(1)$ & $26(2)$ & 1 \\
\hline Heilablóðfall & $0(0)$ & $24(2)$ & 0,4 \\
\hline Fjöllíffærabilun & $2(2)$ & $52(3)$ & 0,57 \\
\hline Djúp skurðsýking & $0(0)$ & $15(1)$ & 1 \\
\hline Bráður nýrnaskaði (RIFLE-flokkur F og E)* & $0(0)$ & $13(0,8)$ & $<0,001$ \\
\hline
\end{tabular}

*Kreatíníngildi vantaði fyrir tvo sjúklinga í yngri hópi og 23 í peim eldri.

lést 41 sjúklingur (3\%) innan 30 daga, par af 6 á skurðarborðinu. Af peim voru 14 í losti áður en peir voru teknir í bráðaaðgerð.

Ekki reyndist munur á hlutfalli sjúklinga í yngri og eldri hópi sem purftu að gangast undir kransæðavíkkun innan 30 daga eftir aðgerð ( $2 \%$ á móti $3 \%, \mathrm{p}=0,77)$ eða endurhjáveituaðgerð ( $0 \%$ á móti $0,4 \%, p=1)$.

Heildarlegutími yngri sjúklinga var að meðaltali tveimur dögum styttri en peirra eldri, eða 9 á móti 11,2 dögum ( $\mathrm{p}<0,001)$.

Heildarlifun yngri sjúklinga var sambærileg peirra eldri eftir 1 ár (99\% á móti $97 \%$, p=0,14) en marktækt betri eftir 5 ár (97\% á móti $89 \%, p=0,04$ ) (mynd 3a). Sjúkdómasértæk lifun var sambærileg fyrir báða aldurshópana en pó sást tilhneiging í átt að betri lifun fyrir yngri sjúklinga (99\% á móti 95\% fimm ára lifun, p=0,07) (mynd 3b).

Í töflu V eru sýndar niðurstöður úr hlutfallslegu Cox áhættulíkani á forspárpáttum lifunar eftir aðgerð. Breytan aldur $\leq 50$ ára reyndist verndandi forspárpáttur (HR 0,45, 95\% CI 0,21-0,96) en sterkustu áhættupættirnir með neikvæð áhrif á lifun voru bráðaaðgerð (HR 2,93, 95\% CI 1,8-4,76) og útfallsbrot vinstri slegils undir $30 \%$ (HR 2,81, 95\% CI 1,52-5,19). Einnig reyndust sykursýki og skert nýrnastarfsemi (GSH $<60 \mathrm{ml} / \mathrm{mín} / 1,73 \mathrm{~m}^{2}$ ) hafa marktækt neikvæð áhrif á lifun, en ekki kyn.

\section{Umræða}

Markmið pessarar rannsóknar var að kanna árangur kransæðahjáveituaðgerða hjá sjúklingum 50 ára og yngri og bera saman við pá sem eru yfir fimmtugt. Alls reyndust 100 sjúklingar af 1626 vera fimmtíu ára eða yngri (6\%), allir skornir á Landspítala á nýlegu 12 
Tafla V. Hlutfallslegt Cox áhættulikan fyrir heildarlifun.

\begin{tabular}{lccc}
\hline & Áhættuhlutfall & $95 \%$ ÖB & p-gildi \\
\hline Aldur $\leq 50$ ár & 0,45 & $0,21-0,96$ & 0,04 \\
\hline Kvenkyn & 1,11 & $0,81-1,53$ & 0,50 \\
\hline Sykursýki & 1,54 & $1,12-2,11$ & 0,008 \\
\hline Brádaaðgerð $^{*}$ & 2,93 & $1,80-4,76$ & $<0,001$ \\
\hline GSH $^{*}<60 \mathrm{ml} / \mathrm{mín}^{\prime} 1,73 \mathrm{~m}^{2}$ & 2,42 & $1,82-3,22$ & $<0,001$ \\
\hline Útstreymisbrot $<30 \%$ & 2,81 & $1,52-5,19$ & $<0,001$ \\
\hline
\end{tabular}

*GSH: gaukulsíunarhraði. ÖB: öryggisbil

ára tímabili. Petta er svipað hlutfall yngri sjúklinga og í erlendum rannsóknum. . $3,14^{2}$

Helstu niðurstöður voru pær að dánarhlutfall innan 30 daga og tíðni alvarlegra fylgikvilla reyndust svipuð í yngri og eldri sjúklingahópi. Minniháttar fylgikvillar reyndust hins vegar marktækt færri meðal yngri sjúklinganna, aðallega vegna lægri tíðni nýtilkomins gáttatifs. Petta skýrir að hluta að legutími yngri sjúklinga reyndist tveimur dögum styttri að meðaltali. Yngri sjúklingar fengu einnig færri einingar af rauðkornapykkni og veikindi peirra virtist bera bráđar að, par sem fleiri úr peirra hópi voru teknir til aðgerðar með flýtingu. Flýting aðgerðar fer sennilega saman við hærri tíðni nýlegs hjartadreps hjá yngri sjúklingum, sem einnig voru með lægra útfall vinstra slegils.

Niðurstöður okkar eru í samræmi við nokkrar erlendar rannsóknir á árangri kransæðahjáveitu hjá yngri sjúklingum sem flestar sýna svipaða tíðni skurðdauða og fylgikvilla, , $1,14,17,18_{\text {par á }}$ meðal rannsókn D'Errigo og félaga par sem dánarhlutfall innan 30 daga var 2,5\%. ${ }^{13}$ Fyrir suma af sjaldgæfari fylgikvillunum, eins og djúpar sárasýkingar og heilaæðaáfall, sást ákveðin tilhneiging í átt að lægri tíðni fyrir yngri sjúklinga, en par sem sjúklingapýðið var tiltölulega lítið var ekki sýnt fram á marktækan mun á hópunum.

Um priðjungur yngri sjúklinga fékk einhvern minniháttar fylgikvilla, borið saman við helming eldri sjúklinga. Mestu munaði um tíðni nýtilkomins gáttatifs sem aðeins greindist hjá $14 \%$ yngri sjúklinga en hjá 35\% peirra eldri. Fjöldi rannsókna hefur sýnt að aldur er einn af sterkustu áhættupáttum gáttatifs eftir hjartaað- gerðir, án pess að ástæðan fyrir pví sé pekkt. ${ }^{18,19}$ Aðrir minniháttar fylgikvillar, eins og pvagfærasýkingar, grunnar skurðsárasýkingar og lungnabólga, voru sambærilegir í hópunum, sem svipar til rannsóknar Mamoun og félaga. ${ }^{18}$

Algengasti alvarlegi fylgikvillinn var hjartadrep í eða eftir aðgerð sem er í samræmi við aðrar rannsóknir, enda pótt tíðni milli rannsókna sé háð pví hvernig hjartadrep er skilgreint. ${ }^{20}$ Í okkar rannsókn var notast við frekar víða skilgreiningu á hjartadrepi en tíðni hjartadreps var engu að síður lág í báðum hópum (3\% á móti $5 \%, p=0,62$ ). Tíðni skurðsýkinga, bráðs nýrnaskaða og fjöllíffærabilunar var einnig sambærileg milli hópa í okkar rannsókn sem er svipað og í rannsókn Rahmnaian og félaga. ${ }^{21,22}$

Ekki reyndist munur á tíðni kransæðavíkkana (2\% á móti $3 \%$, $\mathrm{p}=0,77$ ) eða endurhjáveituaðgerða innan 30 daga ( $0 \%$ á móti $0,4 \%$, $\mathrm{p}=1$ ) vegna endurprenginga. Svipuðum niðurstöðum var lýst í rannsókn Lamy og félaga. ${ }^{20}$

Eins og búast mátti við var heildarlifun yngri sjúklinga betri en peirra eldri, enda skerðast lífslíkur með hækkandi aldri. Ekki kemur pví á óvart að aldur undir fimmtugu skyldi hafa jákvæð áhrif á lifun. Sama á við um neikvæð áhrif bráðaaðgerðar og pegar útfall vinstra slegils er undir 30\%, en hvort tveggja eru vel pekktir neikvæðir forspárpættir lifunar, ${ }^{23}$ líkt og sykursýki og skert nýrnastarfsemi. ${ }^{24}$

Ekki reyndist mikill munur á sjúkdómasértækri lifun á fyrsta ári frá aðgerð en tilhneiging sást í átt að betri lifun hjá yngri

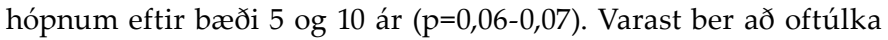
pessar niðurstöður, enda aldur sjúklinga mjög mismunandi milli hópa. Engu að síður gefa pessar niðurstöður vísbendingu um að kransæðahjáveituaðgerðir séu ekki síðri meðferðarkostur fyrir yngri sjúklinga en pá eldri.

Í pessari rannsókn, líkt og fjölda erlendra rannsókna, var ekki hægt að sýna fram á hvaða áhættupættir tengjast snemmkomnum kransæðasjúkdómi. ${ }^{8,9,25}$ Karlmenn voru í miklum meirihluta í báðum hópum en hlutfall sjúklinga með einhvern af helstu áhættupáttunum (háprýsting, blóðfituröskun, reykingar og sykursýki) var mjög ápekkt, eða 93\% í yngri hópnum og 94\% í peim eldri $(p=0,86)$. Pessum niðurstöðum svipar til pess sem lýst hefur verið í öðrum rannsóknum. ${ }^{25}$ Sá áhættupáttur sem virtist skera
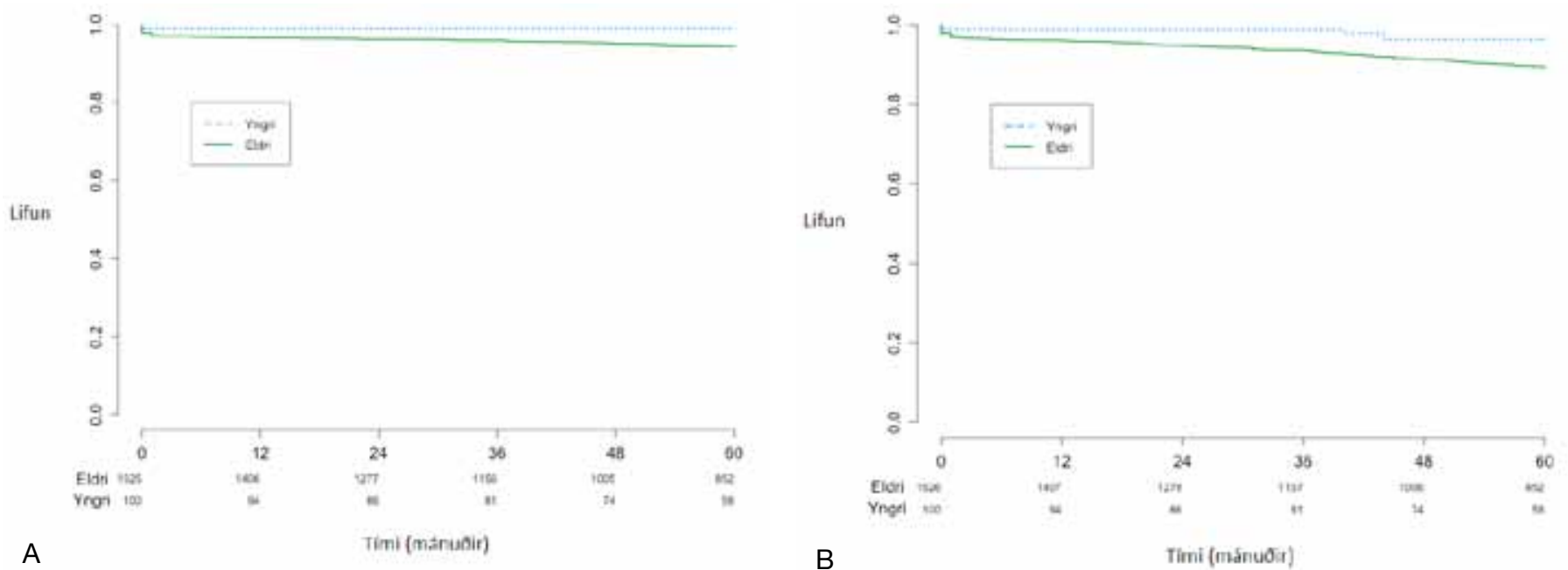

Mynd 3. Heildarlifun (a) og sjúkdómasértæk lifun (b) yngri sjúklinga borin saman við eldri sjúklinga (Kaplan-Meier graf). Á x-ási er fjöldi sjúklinga, eldri og yngri, á hverjum tíma (number at risk). 
sig úr er líkamspyngdarstuðull. Yngri sjúklingar sýndu pannig tilhneigingu til pess að vera heldur pyngri en peir eldri $(p=0,06)$. Svipuðum niðurstöðum hefur verið lýst áður, meðal annars í rannsókn sem bar saman árangur kransæðavíkkunar og kransæðahjáveitu hjá yngri sjúklingum.,14 Ekki lágu fyrir áreiðanlegar upplýsingar um ættarsögu sjúklinganna, enda rannsóknin afturskyggn. Frekari rannsóknir á erfðaefni sjúklinga með dreifðan kransæðasjúkdóm gætu varpað frekara ljósi á orsök sjúkdómsins. Slíkar rannsóknir eru pegar hafnar hér á landi í samstarfi við Íslenska erfðagreiningu.

Yngri sjúklingar voru frekar teknir með flýtingu í aðgerð, eða í 58\% tilfella. Petta er svipað hlutfall og í rannsókn Bardakci og félaga par sem hlutfallið var $60 \%$. Í okkar rannsókn voru $6 \%$ aðgerðanna bráðaaðgerðir, en yngri sjúklingar voru oftar með brátt hjartadrep og greiningu sjúkdómsins virðist pví oftar hafa borið brátt að.

Styrkur rannsóknarinnar er að hún nær yfir 12 ára tímabil og tekur til allra sjúklinga sem gengust undir kransæðahjáveituaðgerð hjá heilli pjóð. Nákvæmar upplýsingar fengust fyrir alla sjúklinga, bæði hvað varðar fylgikvilla en einnig upplýsingar um lifun úr Pjóðskrá og dánarmeinaskrá Embættis landlæknis. Veikleiki við rannsóknina er að hún er afturskyggn. Pví er skráning á einkennum sjúklinga, faraldsfræðilegum páttum og fylgikvillum ekki jafn nákvæm og við framsýna rannsókn. Einnig er veikleiki að upplýsingar um langtímafylgikvilla, til dæmis kransæðapræð- ingar eftir 30 daga vantar. Loks má nefna að sjúklingar í yngri hópi voru aðeins 100 talsins en með fleiri sjúklingum hefði fengist meiri styrkur í tölfræðilegan samanburð hópa, sérstaklega við samanburð á sjaldgæfum fylgikvillum og dánartíðni innan 30 daga.

\section{Lokaord}

Árangur kransæðahjáveituaðgerða hjá yngri sjúklingum er góður hér á landi. Sjúkdómasértæk lifun peirra virðist ívið betri en eldri sjúklinga og tíðni minniháttar fylgikvilla lægri. Einnig er legutími yngri sjúklinga styttri og blóðgjafir fátíðari, enda pótt veikindi peirra virðist bera bráðar að en peirra eldri.

Mikilvægt er að kanna frekar árangur meðferðar við kransæðasjúkdómi hjá yngri sjúklingum hér á landi, ekki aðeins skurðaðgerða heldur einnig kransæðavíkkana. Slík rannsókn er pegar hafin og mun hún vonandi varpa frekara ljósi á árangur meðferðar í pessum sjúklingahópi. Mest spennandi eru samt rannsóknir á erfðum kransæðasjúkdóms en pær munu vonandi skýra af hverju sumir einstaklingar próa sjúkdóminn fyrr en aðrir.

\section{Pakkir}

Pakkir fær Gunnhildur Jóhannsdóttir skrifstofustjóri á skurðsviði Landspítala og Yousef Tamimi fyrir yfirlestur greinar.

ENGLISH SUMMARY

\section{Outcome of myocardial revascularisation in patients fifty years old and younger}

Arnadottir LO'1, Axelsson TA', Helgason D'1, Johannesdóttir $\mathrm{H}^{1}$, Adalsteinsson JA1, Geirsson $\mathrm{A}^{2}$, Sigurdsson $\mathrm{AF}^{3}$, Gudbjartsson $\mathrm{T}^{1,2}$

Introduction: Most patients that undergo coronary artery bypass grafting $(C A B G)$ are around 70 years of age when operated on. We investigated the outcome of CABG in patients 50 years and younger focusing on early complications, operative mortality and long-term survival.

Material and method: A retrospective study on 1626 patients that underwent CABG in Iceland 2001-2012. One hundred patients aged 50 years or younger were compared to 1526 older patients.

Results: The male:female ratio, risk factors and extension of coronary artery disease were comparable in both groups, as was the proportion of patients with left main disease. Left ventricular ejection fraction was significantly lower in the younger patients ( 52 vs. $55 \%, p=0.004$ ) and more of them had a recent myocardial infarction ( $41 \mathrm{vs.} 27 \%, p=0.003$ ). Minor complications were less common in the younger group (30 vs.
$50 \%, p<0.001$ ), especially new onset atrial fibrillation (14 vs. $35 \%$, $p<0,001)$. Chest tube bleeding for the first 24 hours postoperatively was also less in the younger group ( $853 \mathrm{vs} .999 \mathrm{ml}, p=0.015$ ) and they received fewer units of packed red cells ( 1.3 vs. 2.8 units, $p<0.001)$. However, the incidence of major complications was comparable ( 6 vs. $11 \%, p=0.13$ ) and the same was true for 30 day mortality ( 1 vs. $3 \%$, $p=0.5)$. Mean hospital stay was 2 days shorter for younger patients $(p<0.001)$. There was a non-significant trend for improved diseasespecific survival for the younger patients, or $99 \%$ vs. 95\% 5-year survival $(p=0.07)$.

Conclusion: In younger patients undergoing CABG minor complications are less common than in older patients, their hospital stay is shorter and transfusions less common. There was also a trend for improved disease specific survival for the younger patients. 


\section{Heimildir}

1. Arnorsson $T$, Torfason B, Olafsson $G$, Alfredsson $H$, Johannsson KB, Gudbjartsson T, E 24. Hjartaskurðlækningar á Íslandi i 20 ár. Ágrip erinda af Vísindaping Skurðlæknafélags Íslands og Svæfinga- og gjörgæslulæknafélags Íslands. Læknablaðið 2007; 93: 320.

2. Serruys PW, Morice M-C, Kappetein AP, Colombo A, Holmes DR, Mack MJ, et al. Percutaneous coronary intervention versus coronary-artery bypass grafting for severe coronary artery disease. N Engl J Med 2009; 360: 961-72.

3. Barner HB. Operative treatment of coronary atherosclerosis. Ann Thorac Surg 2008; 85: 1473-82.

4. Yan BP, Clark DJ, Buxton B, Ajani AE, Smith JA, Duffy SJ et al. Clinical characteristics and early mortality of patients undergoing coronary artery bypass grafting compared to percutaneous coronary intervention: Insights from the Australasian Society of Cardiac and Thoracic Surgeon (ASCTS) and the Melbourne Interventional Group (MIG) Registries. Heart, Lung Circulation 2009; 18: 184-90.

5. Shroyer ALW, Coombs LP, Peterson ED, Eiken MC, DeLong ER, Chen A, et al. The society of thoracic surgeons: 30-day operative mortality and morbidity risk models. Ann Thorac Surg 2003; 75: 1856-65.

6. Sigurjonsson H, Helgadottir S, Oddsson SJ, Sigurðsson MI, Geirsson A, Arnorsson T, et al. Árangur kransæđahjáveituaðgerða á Íslandi 2002-2006. Læknablaðið 2012; 9: 451-6

7. Yusuf S, Hawken S, Ôunpuu S, Dans T, Avezum A, Lanas $\mathrm{F}$, et al. Effect of potentially modifiable risk factors associated with myocardial infarction in 52 countrie (the INTERHEART study): case-control study. Lancet 2004;364: 937-52.

8. Cole JH, Miller JI 3rd, Sperling LS, Weintraub WS. Longterm follow-up of coronary artery disease presenting in young adults. J Am Coll Cardiol 2003; 41: 521-8.

9. Khawaja FJ, Rihal CS, Lennon RJ, Holmes DR, Prasad A. Temporal Trends (over 30 Years), Clinical Characteristics, Outcomes, and Gender in Patients $\leq 50$ Years of Age Having Percutaneous Coronary Intervention. Am Cardiol 2011; 107: 668-74.
10. Hauser ER, Crossman DC, Granger CB, Haines JL, Jones $\mathrm{CJH}$, Mooser V, et al. A genomewide scan for early-onset coronary artery disease in 438 families: The GENECARD Study. Am J Hum Genet 2004; 75: 436-47.

11. Oddsson SJ, Sigurjonsson H, Helgadottir S, Sigurdsson MI, Viktorsson SA, Arnorsson T, et al. Tengsl offitu við árangur kransæðahjáveituaðgerða. Læknablaðið 2011; 97 223-8.

12. Sigurdsson MI, Helgadottir $S$, Ingvarsdottir IL, Viktorsson SA, Hreinsson K, Arnorsson T, et al. Árangur kransæðahjáveituaðgerða og ósæðarlokuskipta hjá öldruðum. Læknablaðið 2012; 98: 11-6.

13. D'Errigo P, Biancari F, Maraschini A, Rosato S, Badoni G, Seccareccia F. Thirty-day mortality after coronary artery bypass surgery in patients aged $<50$ years: results of a multicenter study and meta-analysis of the literature. J Cardiac Surg 2013; 28: 207-11.

14. Bardakci H, Cheema FH, Topkara VK, Dang NC, Martens TP, Mercando ML, et al. Discharge to home rates are significantly lower for octogenarians undergoing coronary artery bypass graft surgery. Ann Thorac Surg 2007; 83: 483-9.

15. Nashef SAM, Roques F, Michel P, Gauducheau E, Lemeshow S, Salamon R, et al. European system for cardiac operative risk evaluation (EuroSCORE). Eur J CardioThorac Surg 1999; 16: 9-13.

16. Surgeons TSoT. Adult Cardiac Surgery Database Training Manual, v2.73. Adult Cardiac Surgery Data Collection. sts.org/sts-national-database/database-managers/adultcardiac-surgery-database/data-collection:

17. Flather M, Rhee J-W, Boothroyd DB, Boersma E, Brooks $\mathrm{MM}$, Carrié D, et al. The effect of age on outcomes of coronary artery bypass surgery compared with balloon angioplasty or bare-metal stent implantation among patients with multivessel soronary disease: a collaborative analysis of individual patient data from 10 randomized trials. J Am Coll Cardiol 2012; 60: 2150-7.
18. Mamoun NF, Xu M, Sessler DI, Sabik JF, Bashour CA. Propensity matched comparison of outcomes in older and younger patients after coronary artery bypass graft surgery. Ann Thorac Surg 2008; 85: 1974-9.

19. Echahidi N, Pibarot P, $\mathrm{O}^{\prime}$ Hara G, Mathieu P. Mechanisms, prevention, and treatment of atrial fibrillation after cardiac surgery. J Am Coll Cardiol 2008; 51: 793-801.

20. Lamy A, Devereaux PJ, Prabhakaran D, Taggart DP, Hu S, Paolasso E, et al. Off-pump or on-pump coronary-artery bypass grafting at 30 Days. N Engl J Med 2012; 366: 148997.

21. Rahmanian PB, Kröner A, Langebartels G, Özel O, Wippermann J, Wahlers T. Impact of major non-cardiac complications on outcome following cardiac surgery procedures: logistic regression analysis in a very recent patient cohort. Interact Cardiovasc Thorac Surg 2013; 17: 319-27.

22. ElBardissi AW, Aranki SF, Sheng S, O'Brien SM, Greenberg $\mathrm{CC}$, Gammie JS. Trends in isolated coronary artery bypass grafting: An analysis of the Society of Thoracic Surgeons adult cardiac surgery database. J Thorac Cardiovasc Surg 2012; 143: 273-81.

23. Aldea GS, Mokadam NA, Melford Jr R, Stewart D, Maynard C, Reisman M, et al. Changing volumes, risk profiles, and outcomes of coronary artery bypass grafting and percutaneous coronary interventions. Ann Thorac Surg 2009; 87: 1828-38

24. Rosner MH, Okusa MD. Acute kidney injury sssociated with cardiac surgery. Clin J Am Soc Nephrol 2006; 1: 19-32.

25. Khot Un KM, Bajzer CT, Sapp SK, Ohman EM, Brener SI, et al. Prevalence of conventional risk factors in patients with coronary heart disease. JAMA 2003; 290: 898-904. 